\title{
THE DIVERSION OF CULTURE, THE POLITICS OF CULTURAL GEOGRAPHY ${ }^{1}$
}

\author{
NEIL SMITH \\ City University of New York
}

"Power is like a violin. It is held by the left hand and played by the right."

Buenos Aires aphorism

In 1995, US geographer Don Mitchell published an article called "There's no such thing as culture" (MITCHELL, 1995). Mitchell was responding to the explosion of cultural analyses in geography since the 1980 s, to the emergence of cultural studies, and to the so-called "cultural turn" in social theory more broadly. His central argument was not so much that culture as an identifiable facet of human life did not exist, but rather that the ontological status attributed to culture in the "new cultural geography" was specious, illusionary, and politically dangerous. Increasingly rendered an "object" of study in English-speaking geography, culture was now largely reified in US and especially British geography. Mitchell applied to the new cultural geography a parallel critique to that applied by this new cultural geography to its own nemesis, traditional cultural geography. That is, the new cultural geography deploys a "superorganic" conception of culture according to which culture is

${ }^{1}$ O desvio da cultura, a politica da Geografia Cultural refere-se à conferência proferida no Congresso Internacional "Aspectos Culturales en las Geografías Económicas, Sociales y Políticas" (Buenos Aires, 9 a 11 de outubro de 2007), promovido pelas Universidades de Buenos Aires e Universidade Federal Fluminense através da representação conjunta na comissão de Geografia Cultural para a América Latina da União Geográfica Internacional. Sua publicação representa também uma homenagem póstuma ao geógrafo Neil Smith (1954-2012). 
universal, an all-encompassing totality that suffuses all aspects of social life; further, the concept of culture claims for itself some kind of ontological priority as regards social practice. More than a decade later, it is clear that Mitchell's warning failed to stem the tide of "culturalism" (AMIN, 200X) which today dominates the human side of the discipline. Why has the power of "culture" been so pervasive in human geography and in the social sciences more broadly? And how has cultural geography become increasingly a diversion from the kinds of politics that launched it in the first place? In this presentation I want to offer an assessment of the political role that the "new cultural geography" has played in AngloAmerican geography; to suggest ways in which, within a geographical context, the concept of culture might be rescued from itself; and to rethink the connection between cultural politics and political economy.

This lecture comes in four parts. In the first part I will briefly examine the historical contours of cultural geography, precisely because it has lessons to teach us. Second I will offer an appreciation and critique of the "cultural turn." Third I want to argue the ways in which cultural geography has today become a diversion, contributing to an anti-politics. And finally I want to suggest some alternatives.

\section{Historical Contours of Cultural Geography}

Multiple meanings attach to the notion of culture, perhaps because historically, in western societies at least, the concept of culture developed in counterpoint to nature. "Culture" named the process and results of human attempts to separate themselves from nature. According to Raymond Williams (1993), "culture" came to encapsulate three connected realities: it referred to the development of certain ideas and groupings of ideas, to a densely interlinked array of social practices, and ultimately to a way of life. With such a broad-ranging and amorphous definition, resulting in no small part from the fact that culture ("Kultur") came to be defined by the eighteenth century in opposition to an equally allencompassing "nature," it is not difficult to understand how "culture" is amenable to a totalizing treatment. Cultural geography emerged in nineteenth century Europe, still largely undifferentiated from what would now be understood as social/cultural anthropology, and as part of a wider Enlightenment pursuit of moral philosophy. In different national contexts, cultural geography took on different accents and levels of importance, but 
in the European context, this subdiscipline was closely tied to the needs and knowledges of colonial expansion. From Madrid to Berlin, Rome to London, cultural geography identified different human cultures across the world and explained them very much in terms of the characteristics of the regions they occupied. This did not necessarily involve an environmental determinism but very often it did: culture was the product of environment. Or at least, culture could not be understood separate from environment and region - or else what was the rationale for cultural geography. It had multiple motivations and effects, but cultural geography fundamentally contributed to the encyclopedia of colonial knowledge concerning the social reproduction of potential labour power and the social habits and consumption practices of those who might comprise a market for European factories.

In Britain, cultural geography was especially tied to colonial expansion whereas an emerging social geography addressed many of the same kinds of questions at home. In Germany, by contrast, the intellectual opposition of "Kultur und Natur" was so strong that cultural geography dominated the human side of the field. This was the tradition that most influenced US geography in the late nineteenth century, and as the discipline began to develop its social rather than physical side after World War I, cultural geography was human geography. However progressive in this context, Carl Sauer (1925) was a central early figure in mid-twentieth century cultural geography in the United States, helping to establish the superorganic conception of culture which became the norm. A quarter century later, one of the most prominent figures in twentieth century cultural geography in the United States, Wilbur Zelinsky, expressed this superorganicism precisely:

... the totality of culture is much greater than the simple sum of its parts, so much so that it appears to be a superorganic entity living and changing according to a still obscure set of internal laws. Although individual minds are needed to sustain it, by some remarkable process culture also lives on its own, quite apart from the single person or his volition, as a sort of 'macro-idea', a shared abstraction with a special mode of existence and set of rules (ZELINSKY, 1973, 71).

In disciplinary terms, the cultural turn in geography, beginning in the 1980s reacted against this superorganic vision of cultural geography. Not only was cultural geography criticized as totalizing, but its evident 
idealism - culture as an idea - was also challenged. Long before this direct challenge, cultural geography of the colonial/American sort had become moribund, lifeless, in the face of far more vibrant alternatives: namely, the quantitative revolution of the 1960s quickly followed by the social theory revolution of the 1970s - marxism, phenomenology, feminism, political ecology, postcolonial theory, and much more. We are still living through the latter period - and the backlash against it - notwithstanding the resurgence of quantitative positivism at the hands of GIS technologies, and the increasing divorce (in the Anglo-American world at least) of intellectual social theory from class politics and from many other political movements.

Against this historical backdrop, the new cultural geography of the 1980s and afterward promised a radically new and politically energized approach to the connection between culture and politics, geography and cultural practice. It was fuelled not just by a narrow critique of traditional twentieth century cultural geography, although that played a larger part in the earliest work than is generally acknowledged. It was fuelled too by a combination of other influences. First, the new cultural geography was part of a larger shift in left politics toward a politics of culture. At one level this shift was prompted by the political movements of the 1960s as they became institutionalized in identity politics, in the broadest sense. Arguably the major concern for feminist political writing in the early 1980s, for example, was, as political theorist Nancy Hartsock put it at the time, that feminism lacked its own coherent theory. That was about to change, and with a vengeance. In search of a theoretical foundation for these avowedly anti-foundational movements, feminist theory, queer theory and post-colonial theory galvanized an extraordinary creativity in social scientific research. Second, and obviously related, the new cultural geography drew inspiration from the brief flowering of postmodernism in the 1980s and the early 1990s, and its emphasis on the discursive interpretation of material and popular culture. This shift had nothing to do with the existing anthropological literature on material culture; rather, it emphasized the consumer cultures of the period in Europe and North America. Nothing in this period was more overanalyzed than Madonna's clothing choices. Cultural studies became the academic incarnation of this work, its own ghetto of celebratory representationality, increasingly distanced from the social experiences of many it represented. Third, what postmodernism skimmed over in its search for the weightiest meaning embedded in the most superficial cultural gesture, poststructuralism 
seemed to backfill. The politics of poststructural theory, especially but not only that of Foucault, was twisted in translation into English as a micropolitics of the cultural interstices of everyday life, foundationally antagonistic to any kind of political economy (or even cultural politics) that did not reaffirm a certain post-economic individualism. But to my reading, Foucault, whose work is so thoroughly rooted in Marx (even in critique), and who is nevertheless generally treated in Anglo-American circles as the ant-Marx - Foucault must be defended. In the first place he must be defended against so many English-language Foucauldians. But that would be to embark on a different project.

This brings us to the fourth rationale for the new cultural geography. More than anything the new cultural geography represented a reaction to the power of marxist and political economic analyses in geography from the 1970s onward. The new cultural geography galvanized critiques from an eclectic range of theoretical influences to present an alternative to $1970 \mathrm{~s}$ and 1980s political economy. From the late 1960s to the mid 1980s, marxist work had taken English-speaking geography by storm. Marxism found itself strangely powerful in the discipline of geography in the early years of the Thatcher, Reagan and Kohl regimes and at a time when the US supported more criminal dictatorships in Latin America than at any time since.

If the strength of marxism in Anglo-American geography was surely an untenable situation in the long run it was a heady prospect in the short term. The older superorganic culturalism, from Sauer to Zelinsky, seemed to many still to be struggling to enter the twentieth century and was no serious obstacle to marxist work. And the "new" positivist geography, which with its scientific matrices, equations and algorithms had sparked such hope in the early 1960s, was also for a quite different reason incapable of neutralizing marxist theory. Against the backdrop of the $1960 \mathrm{~s}$ and 1970s revolts, the new positivism seemed dramatically irrelevant to the political demands of the time and to any attempt to understand the "production of space," as Henri Lefebvre would call it at the time. Anglo-American geography had never had any deeply rooted social theory; even its pragmatism was untheorized in the United States where theories of pragmatism ruled political philosophers for much of the century. Without significant social theory, geography at best shared certain social or scholarly prejudices that were often borrowed, never well thought out: environmental determinism, positivism, cultural historicism, 
and so forth. The discipline did not have the theoretical sophistication to deal with the marxist challenge, or even to deflect it; in short, it had no immune system to fight this social theoretical novelty which provided deeper and broader explanations for the social nature of geography than had ever been proposed in the past. Many young positivists quickly and unceremoniously abandoned positivism and realigned themselves with marxist social theory in one form or another. David Harvey may have been the most prominent but he was only one of many: Eric Sheppard, Michael Webber, Doreen Massey, Jim Blaut, among many others in AngloAmerican geography.

The new cultural geography of the 1980s and afterward was based on a fundamental challenge to the intellectual power and claims of this marxist work. It insisted that culture and not just the economy was political too. It mobilized critiques of structuralism - especially critiques of Louis Althusser - as if they were critiques of marxism tout court (DUNCAN; LEY, 1982). With only passing attention to the work it would dismiss, but bolstered by identitarian, culturalist and post-structuralist critiques, the new cultural geography focused especially on questions of consumption. Social production, for the new cultural geography, was now passé in a supposedly postindustrial world, unless one was concerned with the production of representations, the making of discourse. Otherwise, the emphasis lay on the mode of consumption and the cultural field through which images, social differences, and cultural ideas were consumed. The French psychological theory of Lacan, and the psychologically influenced theory of Derrida or Kristeva, played a particularly important role here. The politics of consumption became entwined with the politics of subject formation; whereas social production might be seen as narrowly responsible for the creation of economic value, consumption became increasingly connected to the issue of subject construction.

\section{The Cultural Turn - a Critique}

There can be no questioning the insistence on the politics of culture, nor indeed the importance of such an insistence in the 1980s and afterward. There are a number of reasons for this, but in addition to the intellectual and political developments already mentioned, the world looked very different in this period compared to the post-world war II era. The 1980s ushered in a period of massive economic expansion in the 
centers of European and North American power, and even more unprecedented economic growth among elites, dictatorships, ruling classes and professional classes throughout the world. This brought wealth for many and burgeoning consumption and a sense that in a new supposedly postindustrial world the political questions may be changing. The cultural turn in academia in many ways represented a response to these shifts. The explosion of "image capitalism," facilitated by computer, internet and satellite technologies that were unknown to the world's masses two decades ago, did not invent Bollywood or hip hop, nor Google nor My Space social networking, nor myriad other cultural productions, but "image capitalism" did bring about the globalization of these cultural forms. The cultural turn, and with it cultural geography, responded with the claim that relations of consumption now dominated, even eclipsed, relations of production, and the focus of cultural scholarship adjusted accordingly to such questions of consumption.

It is fair to say that in its earliest versions, the new cultural geography attempted to fill in a vital and missing area of scholarship. As it evolved, however, this focus on consumption has become more and more exclusionary and reductionist. First, what some people in the so-called West still call a postindustrial world, in which culture and consumption rule, is actually a quite limited phenomenon. The luxury of distance from the production process is both a class question and a question of geography. In European and North American societies where the percentage of extraction and manufacturing employment is declining, class divisions have become more not less deep: uneven development has become more not less extreme. While workers' wages have remained constant or even declined over the last four decades in the United States, the incomes of the highest earning 1\% have risen $300 \%$. The level of inequality in the US, as measured statistically by Gini coefficients, is much more extreme than in 1970 and exceeds the comparable rates for even Russia, China or India. The pay of corporate Chief Executive Officers (CEOs) in the US was 42 times that of the average wage worker in 1982; today it is an astonishing ratio of 364:1. In 2006, four corporate bosses in equity and hedge fund (financial) companies actually took home an income of over $\$ 1$ billion. The top 20 US CEOs - corporate bosses - averaged $\$ 658$ million each, last year - a cool \$2.8 million per working day of the year. On that kind of salary, you can afford a lot of consumption. The unequal share of wealth in the United States has returned to the levels of the 1930s Depression. 
Second, this criminal intensification of uneven development is global and local as much as national. The productive work that sustains the US ruling class, and Europe and North America more generally, increasingly takes place in the cities and villages of China, the factories of Sao Paulo and Mumbai, the smaller cities of South and East Asia, Latin America, and to a far more limited extent, sub-Saharan Africa. There too, the inequalities between rich and poor are expanding to unprecedented levels. In the heartlands of Europe and North America - and it is important to remember that the US remains the world's largest manufacturing economy, still accounting for more than a fifth of global production - this work disproportionately employs women, immigrants and minorities, or else it is ideologically disguised as some kind of "service" work.

About these changing realities, cultural geography has been remarkably silent. Insofar as these realities are "out of sight" they are too readily "out of cultural mind." In fact, there are more workers in the world today, more people involved in social production, than at any previous time, but the cultural geography of work barely exists as a focus of academic research. In this respect, the new cultural geography, which has prided itself on colonizing the cutting edge of social change - the new power of consumption - is actually dramatically irrelevant to much that is happening in the world and to large parts of the lives of the majority of people. From this point of view, the new cultural geography at least in the English-speaking world has increasingly come to represent an extremely ethnocentric and class-privileged view of the world.

Third, it is important to examine critically the nature of the new cultural geography's critique of marxist analysis. For the new cultural geography, marxism was incapable or uninterested in engaging a cultural critique. But this is patently false. Quite apart from the cultural writings of classical marxists - Trotsky on art, for example - one can think of Gramsci whose political writings completely embraced the question of social reproduction and consumption. Or there is Henri Lefebvre, a fervent marxist critic of much 1970s French poststructuralist theory (despite the efforts of English-language cultural geographers to absorb him into exactly that poststruturalism) - Lefebvre who in the 1940s, while a member of the communist party, began pioneering the analysis of everyday life. Marxists such as Raymond Williams and Edward Thompson for decades advanced a cultural marxist critique, and the cultural marxist tradition was even stronger in continental Europe - Perry Anderson's classic History of 
Western Marxism never mentioned political economy - and in Latin America. It is certainly true that the revival of marxism in Englishspeaking geography oriented significantly toward a spatialized political economy. Traditional economic geography of the 1960s recognized no social or cultural difference at all, except via income, employment status and other such statistical measures, and marxist work insisted on the discussion of social class and race, social movements and environment, gender and imperialism. A dispassionate examination of the pages of Antipode: a Radical Journal of Geography, the major outlet for radical ideas after 1969 quickly confirms the diversity and indeed eclecticism of radical geography in the 1970s and 1980s. And even the most prominent marxists in geography have never been focused purely on the economic. David Harvey, to take the most obvious example, was concerned about the cultural geography of Paris throughout his thirty-year analytical involvement with that city (HARVEY, 1985; 2003). And there are many other examples. This makes it even more significant that the new cultural geography has tried to fashion itself in such direct opposition to marxist political economy. Why is the new cultural geography so opposed to political economy? Why does the new cultural geography seem more drawn to Madonna, for example, to discourse on cultural fashion, or to used-clothing sales - none of these especially geographical concerns - than it does to the questions of everyday life among workers in the Chinese factories that make the fashions that Madonna wears?

My critique here is not that a new cultural geography was unnecessary; clearly it was. Rather, the work done by the new cultural geography today is very different from the work it might have done given its origins. The politics of consumption is an inherently important topic, but not when the focus on culture and consumption becomes an excuse to exclude cultures of production and the working lives of people around the world. The social construction of the subject, as pioneered in poststructuralist work, is perhaps even more important insofar as it can help provide an understanding of how and why people abdure or tolerate repressive power applied to them, become complicit in that power, and how and why they revolt against that power. But this perspective has lost any utility when it refuses to recognized structured social differences of class, for example, and cuts itself off from social movements, including labour and class movements that are (among others) capable of making social change. It has lost its utility, in short, when it becomes a powerless social constructionism, often expressed in the passive voice - "the other is 
constructed as ...." - instead of explaining how and especially why power relations work in everyday life as they do. And how these power relations, which after all are deeply ingrained in the productions of cultural space - a point made by Professor Lobato Correa and a point not lost to traditional cultural geography - how these power relations might be overthrown.

\section{Dancing from Politics}

Discursively and ideologically, the seemingly political mission of the new cultural geography, at least in the English-speaking literature, is repeated over and over again, or simply taken for granted. But it is now a largely empty claim. When second hand shopping in Northern England or the political culture of gentrified New York restaurants become the leading edge of the new cultural geography, it is not unreasonable to ask what is actually left of the politics. Cultural geography, we have to conclude, has distanced itself from politics in the same way that it earlier distanced itself from political economy. The politics of culture has become an empty assertion, a nostrum, a shibboleth, a token of resistance without any substance. Politics has in fact been replaced by two things: first, the quintessentially poststructuralist belief that if one simply changes the discourse, the world will follow. The idealist fallacy here, of course, is that while the power of ideas can never be underestimated, it takes social action to put them into practice. Second, and closely connected, politics in the new cultural geography is reduced to ethics. The vacuum vacated by politics is increasingly filled by an ethical individualism that sees no political responsibility except for a certain moral correctness. Sanctimony substitutes for organization. Liberalism returns via the wide open front door of a pretend radicalism.

The old cultural geography withered and became vulnerable to critique precisely because it failed to remain relevant in a world where the old superorganic categories of discrete cultures, national cultures, and culturally defined civilizations no longer made sense. As the apparent postwar fixity of nation states and a First, Second, and Third World dissolved in the 1970s, the new cultural geography both expressed the emerging mobility and social flexibility of a globalized world but also, especially in its postmodern incarnation, came too easily to function as a discourse for the consumption ideologies of globalization itself. The cultural turn increasingly provides a new technology of how the natives at 
home consume. Let me put this even more directly. What began as an oppositional project in the 1980s, a critique of a traditional cultural geography that was unable to extract itself from the colonial and expansionist agendas of national states, too often ended up, however unintentionally, as a barely critical and often celebratory discourse of globalization. Diversity has moved from being a radical demand in terms of race, gender and sexuality to a policy enthusiastically supported by governments and corporations around the world. Multiculturalism, also once a radical demand, is now also state policy despite the continuation of racism, gender and sexual discrimination. To the extent that the new cultural geography does not critique this state of affairs - diversity and multiculturalism as establishment policy - but continues to champion ideas that are now state policy, it has become complicit in the work of global neoliberalism. The economy may indeed be ideologically culturalized, but on whose terms, and for what social goals? For the new cultural geography, politics increasingly happens by osmosis or simply assumption.

Not only has the new cultural geography progressively denied political economy, but it has largely avoided commentary on the major political events of the last few years. There are, to be sure, discursive analyses of the racism that has accompanied the manufacturing of Arabs and Muslims as the new enemies of bourgeois democracy and free markets. But in a period of brutal war where are the careful cultural geographical critiques of Samuel Huntington's Clash of Civilizations? No other text in broad support of the wars in Afghanistan and Iraq and the potentially imminent escalation into Iran and/or Syria calls out for critical cultural geographical attention? Instead, risking the same fate as the traditional cultural geography it still strives to displace, the new cultural geography has proven irrelevant and not even especially interested in tackling these kinds of political issues that appear in blogs, on the internet, and on the front pages of newspapers every day. The most apt comparison I can think of is US cultural and political geography in the 1930s which, confronted with the rise of geopolitics, was paralyzed by its inability to see geography in a political register. Geography, they believed, was science, and politics was something completely different. There were no politics in science, they argued. Their refusal to become publicly involved condemned American geography to several decades of irrelevance.

The situation with the new cultural geography today is different, obviously, but not very different. In an ironic twist, this new cultural 
geography rooted especially in Britain has become the mirror image of 1930s US geography - a copy except reversed as in a mirror. The new cultural geography already sees itself as necessarily political - politics is in its founding DNA, inside the microcosmic interstices of its own being. The wars in Afghanistan and the Middle East may appear as political to some, but they may not be especially political for other in the new cultural geography. Hence the lack of attention by such cultural geographers to an ideologue like Huntington. In this perspective, geopolitical or geoeconomic war is just boring - not at all fun to research. Cultural geography, the argument goes, has far more important questions.

Like dancing. In case you think that I am exaggerating about the political decay of the new cultural geography, or that I am somehow misinterpreting its trajectory, let me quote as evidence the following from a very prominent English cultural geographer who has devoted several articles to, among other important issues, dancing. In a new book, he writes:

In days when the Iraq War, Afghanistan, 9/11, 7/7 and other such events often seem to have claimed total occupation of the Western academic psyche, and many academics have reacted with mammoth statements about warfare, imperialism, capitalism, global warming and numerous other waypoints on the road to perdition, it is difficult to remember that other kinds of political impulse might also have something to say.... (THRIFT, 2007)

The cultural politics of war, and of an estimated 1.2 million Iraqis needlessly killed, have clearly got in the way of this scholar's comfortable world view. And what might this world view look like? Apart from dancing? At a time when airports have been turned into major palaces of consumption and into extraordinary spaces of state security against the people, this same geographer has declared to his university that he wants to turn the university into "an academic Heathrow." If that is the new cultural geography in action, we surely need alternatives.

The new cultural geography has indeed become a diversion. On the one hand it can be as much fun as - dancing. On the other hand, it increasingly deliberately diverts our attention from anything political. There might be a case here for arguing that the intense angst around the Iraq war itself produced social insecurity as a means of social control - but 
that is not our dancer's argument. The intent to divert our political attention could hardly be more obvious.

As London based cultural theorist Slazoj Zizek (NYT 10/11/07) has recently argued, "All human sciences are turning into a branch of cultural studies," and "culture," he goes on to say, "has commonly become the name for all those things we practice without taking seriously." In the same spirit, the new cultural geography in fact looks like a paradigmatic case of what Manchester geographer Erik Swyngedouw (2007), in a keynote lecture to the Royal Geographical Society in London, has described as the "post-political." In a post-political world, for Swyngedouw, the signs, representations and claims of politics are mobilized against any effective politics at all.

\section{After the New Cultural Geography: Politics by the Front Door}

Let me conclude by asking but not necessarily answering a question: How do we reintroduce politics to cultural geography, or indeed cultural geography to politics? In general, I think that a revived cultural geography needs to be critically involved in the major political issues of the day, and I will make several modest proposals. First, it is not too late for a critique of Huntington's Clash of Civilizations, a critique which may not any more grab headlines but which might be valuable insofar as the civilizational ideology of Huntington is widely and deeply believed and needs to be exposed. How does the unspoken geography of resource location, social control capital accumulation and consumption intersect with Huntington's civilizational map of the world? Second, I would agree with Benno Werlen that cultural geography should have a voice in environmental issues, a voice that has till now been largely missing, especially in discussions of sustainability. But this issue highlights precisely the importance of connecting a cultural with a political economic approach. Why? Because political economic and political ecological critiques of sustainability are beginning to argue that the language of sustainability is now so generally co-opted that it has no radical or critical intent whatsoever. It is less the environment that is to be sustained today; apparently; rather the sustainability of profit rates is the central question. A cultural geography that engages the ideology of sustainability without taking this critique seriously does little more than perpetuate that ideology - divert us from the cultural damage done under the flag of sustainability. 
Third, I think we need a broader critique of how politics works through culture, and vice versa. An identity model is no longer sufficient, if it ever was. A recently published book by the literary critic, Tim Brennan, might be helpful here. In Wars of Position, Brennan (2006) argues that since the 1980s, largely coincident with the rise of this latest round of neo-liberal globalization, the nature of politics has changed. In an earlier period, politics was about belief. People organized and mobilized on the basis of what they believed to be right, and against inequality, exploitation, oppression and other wrongs. Today, Brennan argues, politics has increasingly become about being. Who we are, our identities, has become more important in defining politics than what we believe. In terms of cultural geography, an identity politics can lead right back to a traditional assertion of identity as an expression of place. Alternatively, it can lead away from geography entirely as in much of the new cultural geography. In either case there is a misreading identity. Identity politics of the 1970s and 1980s began as a radical challenge to traditional modes of politics which either ignored or marginalized questions of race, gender, sexuality and other forms of identity. It provided a theoretical understanding of multiple oppressions but also a basis for social solidarity. But these radical, oppositional roots of identity politics are now largely withered. Instead, today, it is possible to see identity politics as a kind of ideological therapy entirely consistent with globalization. Its slogan might be: "Arise you individuals of a globalizing world. You have nothing but your identities to lose." What better a therapy for a globalizing world which threatens the specificity of identity than a politics that emphasizes diversity and everyone's multicultural uniqueness. Which brings us back to Don Mitchell and why "There's no such thing as culture." Contradictory as this sounds, perhaps it is necessary for us to learn again that "there is no such thing as culture," at least in its present meaning, before a more politically vibrant cultural geography can be reconstructed.

\section{O DESVIO DA CULTURA, A POLÍTICA DA GEOGRAFIA CULTURAL}

Resumo: Nas décadas de 1980 e 1990, uma nova geografia cultural emergiu, prioritariamente como uma resposta à proeminência que o marxismo e da economia política haviam assumido no campo da Geografia desde a década de 1970, mas também como um reflexo mudanças sociais mais amplas do capitalismo avançado. Ao colocar em questão a prioridade 
concedida à esfera da produção na análise geográfica, essa nova geografia cultural deslocou sua ênfase de estudo para questões referentes ao consumo, à representação e à identidade. Este artigo possui três objetivos centrais. Em primeiro lugar, procura avaliar o papel político que a "nova geografia cultural" desempenhou na Geografia anglo-americana. Em segundo lugar, pretende sugerir formas por meio das quais, em um contexto geográfico, o conceito de cultura possa ser resgatado de si mesmo. Por fim, o artigo procura repensar as relações entre política cultural e economia política.

Palavras-chave: Nova geografia cultural; virada cultural; política; economia política.

\section{THE DIVERSION OF CULTURE, THE POLITICS OF CULTURAL} GEOGRAPHY

Abstract: The 1980s and 1990s witnessed the emergence of a new cultural geography, primarily as a reaction to the power that Marxism and political economy had acquired in the field of geography from the 1970s onward, but also reflecting broader social changes in advanced capitalism. Putting into question the priority given to the realm of production in geographical analysis, this new cultural geography shifted emphasis instead to matters of consumption, representation and identity. This paper has three basic objectives. First, it is intended as an assessment of the political role that the "new cultural geography" has played in Anglo-American geography. Second, it seeks to suggest ways in which, within a geographical context, the concept of culture might be rescued from itself. Finally, it aims to rethink the connections between cultural politics and political economy.

Keywords: New cultural geography; cultural turn; politics; political economy.

\section{BIBLIOGRAPHY}

AMIN, S. (200X) Monthly Review, New York: Bloomsbury Publishing. ${ }^{2}$

${ }^{2}$ Referência incompleta no original. 
BRENNAN, T. (2006) Wars of Position: The Cultural Politics of Left and Righ, New York: Columbia University Press.

MITCHELL, D. (1995) There's no such thing as culture, London: The Royal Geographical Society.

SAUER, C. (1925) The Morphology of Landscape, California: University of California Press.

THRIFT, N. (2007) Non-representational theory, London: Routledge.

WILLIAMS, R. (1993) Keywords, London: Routledge.

ZELINSKY, W. (1973) The Cultural geography of the United States, Englewood Cliffs, New Jersey: Prentice Hall. 